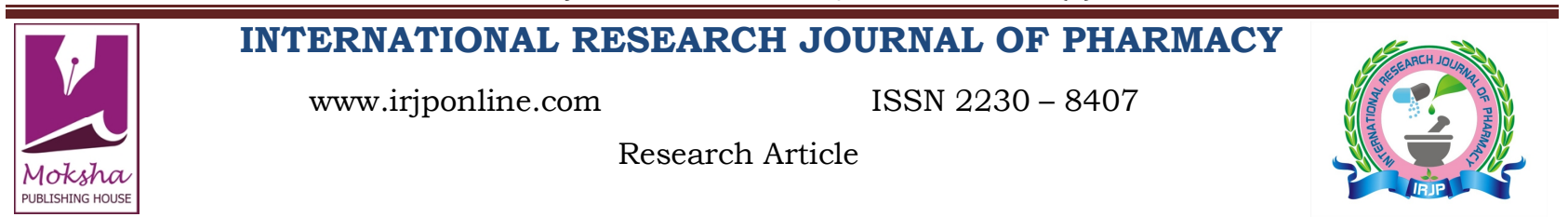

\section{ANALYTICAL STUDY OF CURCUMIN CONTENT IN DIFFERENT DOSAGE FORMS CONTAINING TURMERIC EXTRACT POWDER AND TURMERIC OLEORESIN}

Rane Rajashree*, Gangolli Divya, Patil Sushma, Ingawale Kanchan, Kundalwal Sachin

Piramal Enterprises Ltd., Goregaon, Mumbai, Maharashtra, India

Email: ranearajashree@gmail.com

Article Received on: 13/01/13 Revised on: 01/02/13 Approved for publication: 10/03/13

DOI: 10.7897/2230-8407.04338

IRJP is an official publication of Moksha Publishing House. Website: www.mokshaph.com

(C) All rights reserved.

\section{ABSTRACT}

Different dosage forms namely tablets, capsules, creams and syrups were analysed for curcumin content, by the well-known spectrophotometric method. Turmeric extract powder was used as a source of curcumin in capsule and tablet formulations. Turmeric oleoresin was used as a source of curcumin in cream formulation. Additionally, syrup formulations containing turmeric extract powder as well as turmeric oleoresin, separately, were also tested for their curcumin contents.

Analytical results for curcumin content were found to be satisfactory in tablets and capsules containing turmeric extract powder. Whereas, in case of syrup containing turmeric extract powder, analytical findings for curcumin content, did not meet the expected specifications. However, when turmeric powder was replaced by the same quantity of oleoresin having similar strength, in cream and syrup, the results met the expected values, at the initial stages. But analysis data over a period of 1 Year testing, showed declination in the initial findings due to unstability of turmeric oleoresin for long duration.

Keywords: Turmeric extract powder, turmeric oleoresin, curcumin content, analytical estimation, spectrophotometric method.

\section{INTRODUCTION}

Ayurveda, the ancient Indian medicine system, is now widely recognized as an effective, alternate and complementary medicine. Ayurveda literally means 'Science of Life.' Plant based medicine is one of the central pillars of Ayurveda ${ }^{1}$. Plants and their products are being used in medicine, due to their better cultural acceptability, better compatibility with the human body and lesser side-effects ${ }^{2}$.

Turmeric is one of the most commonly used ingredients in home remedies and Ayurvedic medicines, since times immemorial, due to its multiple uses as a health promoter as well as for treatment of numerous chronic diseases. It is a golden colored spice, and is used in cooking, in the Indian subcontinent. Due to its color and taste, it is named as "Indian Saffron." Turmeric is also used as a food preservative and as a dye in textile industry ${ }^{3}$.

Curcuma longa Linn. (Turmeric or Haldi), Family: Zingiberaceae, is a small perennial herb, native to India, bearing many rhizomes on its root system, which are the source of its culinary spice. The turmeric rhizomes are boiled, dried and made into a yellow colored powder, which is employed as a coloring agent and a condiment, entering largely into the Indian pickles and curry powders ${ }^{4}$. The rhizome is pungent, bitter, heating, laxative, anthelmintic,vulnerary, tonic, alexiteric and emollient. It improves the complexion, is useful in "kapha" and "vata", diseases of the blood, leucoderma, scabies, urinary discharges, inflammations, ozoena, bad taste in the mouth, biliousness, dyspepsia, elephantiasis, snake-bite, smallpox, swellings, sprains, cutaneous infections, colic and amenorrhoea. The juice of fresh rhizome is applied to wounds, bruises and leech bites ${ }^{5}$.

Turmeric contains a wide variety of phytochemicals including curcumin, bismethoxycurcumin, demethoxycurcumin, zingiberene, curcumenol, curcumol, eugenol, tetrahydrocurcumin, triethylcurcumin, turmerin, turmerones and turmeronols.

Curcumin falls into the the category of curcuminoids, It is the phytochemical that gives the yellow color to turmeric and is now recognized as being responsible for most of its therapeutic effects. Curcumin exhibits antioxidant, antiinflammatory, antiviral, antibacterial, antifungal and woundhealing properties. More recently, scientists have studied its anticancer activities as well as its benefits to chronic conditions such as diabetes, allergies, arthritis, Alzheimer's disease, multiple sclerosis, HIV replication, septic shock, multidrug resistance, cardiovascular diseases, cardiotoxicity, gall stones, lung fibrosis, inflammatory bowel diseases, nephrotoxicity and liver injury. Thus, curcumin holds a lot of promise in the treatment of a wide range of diseases and is used in various forms, in different medicaments and formulations ${ }^{1}$.

Curcumin composes only $4 \%$ of the turmeric rhizome, therefore necessitating the need for enrichment. Thus, turmeric rhizome is extracted with various solvents and the final extracted form can be either in powder or oleoresin form.

Turmeric extract powder is prepared by extracting turmeric powder with ethanol, by soxhelation and then concentrating under reduced pressure and air drying. Turmeric oleoresin is a deep brownish-orange viscous oily fluid, also prepared by the extraction of turmeric powder using organic solvents ${ }^{6}$. Stability of turmeric oleoresin was studied by Zaibunnisa et $\mathrm{al}^{7}$ and suggested that the stability of turmeric oleoresin encapsulated with B-cyclodextrin (BCD) stored at $5^{\circ} \mathrm{C}$ in dark container can be extended to 154 days.

As curcumin is one of the major constituents of turmeric formulations and is responsible for most of the therapeutic actions, estimation of curcumin is considered as an important quality parameter as far as physico-chemical and stability studies are concerned. The curcumin content in different formulations, may not meet the expected values, as the various enriched forms of turmeric, like extract powder or oleoresin, differ with respect to their solubility. Hence, it is necessary to monitor the curcumin content in different formulations, against the theoretically expected value of Active Pharmaceutical Ingredient (API), used in the 
respective formula. This is also important from the stability point of view.

\section{MATERIALS AND METHODS}

Four different dosage forms namely tablet, capsule, syrup and cream are selected for the evaluation of Curcumin content. Presence of piperine is seen in each formulation along with curcumin. Curcumin with piperine increases the absorption of and pharmacological effects of curcumin in the body. Experiments carried out on mice by Rinwa et $\mathrm{al}^{8}$ clearly suggest that piperine enhances the bioavailability of curcumin and potentiate its protective effects against CUS induced cognitive impairment and associated oxidative damage.

Various standardised classical and instrumental methods are available for estimating curcumin content. The UV/visible spectrophotometric method ${ }^{9}$ is one of the most reliable and popular methods, and hence, this method was used for the estimation of curcumin, in the various formulations. Before recording the absorbance reading at $425 \mathrm{~nm}$ on UV-Visible spectrophotometer, it is calibrated using standard method ${ }^{\mathbf{1 0}}$.

The quantity of sample taken, the dilutions and the calculations, in case of all the different turmeric formulations are as mentioned below:

Turmeric (Haldi) (Curcuma longa) extract powder: $0.1 \mathrm{~g} \rightarrow 100 \mathrm{ml} \rightarrow 0.5 \mathrm{ml} \rightarrow 50 \mathrm{ml}$

Content of Curcumin $(\% \mathrm{w} / \mathrm{w})=$

[( A / 168) X (100/W) X 10]

Where, $A=$ Absorbance Reading of the sample ;

$\mathrm{W}=$ weight of the sample in $\mathrm{g}=0.1$

Turmeric (Haldi) oleoresin:

$0.1 \mathrm{~g} \rightarrow 100 \mathrm{ml} \rightarrow 0.2 \mathrm{ml} \rightarrow 25 \mathrm{ml}$

Content of Curcumin $(\% \mathrm{w} / \mathrm{w})=$

[( A / 168) X (100/W) X 12.5]

Where, $\mathrm{A}=$ Absorbance Reading of the sample ;

$\mathrm{W}=$ weight of the sample in $\mathrm{g}=0.1$
Tablet with Turmeric (Haldi) extract powder:

$0.2 \mathrm{~g} \rightarrow 100 \mathrm{ml} \rightarrow 5.0 \mathrm{ml} \rightarrow 50 \mathrm{ml} \rightarrow 5.0 \mathrm{ml} \rightarrow 50 \mathrm{ml}$ Content of Curcumin $(\mathrm{mg} /$ tablet $)=$

[( A / 168) X (100/W) X 10 X Average weight of 20 tablets in $\mathrm{g} X(1000 / 100)]$

Where, $A=$ Absorbance Reading of the sample ;

$\mathrm{W}=$ weight of the sample in $\mathrm{g}=0.2$

Capsule with Turmeric (Haldi) extract powder:

$0.2 \mathrm{~g} \rightarrow 100 \mathrm{ml} \rightarrow 2.0 \mathrm{ml} \rightarrow 50 \mathrm{ml}$

Content of Curcumin (mg/capsule $)=$

[( A / 168) X (100/W) X $2.5 \times$ (filled average weight of 20 capsules in $\mathrm{g}) \mathrm{X}(1000 / 100)]$

Where, $A=$ Absorbance Reading of the sample ;

$\mathrm{W}=$ weight of the sample in $\mathrm{g}=0.2$

Cough syrup 1 with Turmeric (Haldi) extract powder:

$5 \mathrm{ml} \rightarrow 100 \mathrm{ml} \rightarrow 5.0 \mathrm{ml} \rightarrow 10 \mathrm{ml}$

Content of Curcumin $(\mathrm{mg} / 100 \mathrm{ml})=$

[( A / 168) X (100/ V) X 0.2 X 1000]

Where, $\mathrm{A}=$ Absorbance Reading of the sample ;

$\mathrm{V}=$ Volume of the sample in $\mathrm{ml}=5$

Cough syrup 2 with Turmeric (Haldi) oleoresin:

$1 \mathrm{ml} \rightarrow 100 \mathrm{ml} \rightarrow 5.0 \mathrm{ml} \rightarrow 50 \mathrm{ml}$

Content of Curcumin $(\mathrm{mg} / 100 \mathrm{ml})=$

[( A / 168) X (100 / V) X 1 X 1000]

Where, $A=$ Absorbance Reading of the sample ;

$\mathrm{V}=$ Volume of the sample in $\mathrm{ml}=1$

Cream with Turmeric (Haldi) oleoresin:

$4.0 \mathrm{~g} \rightarrow 100 \mathrm{ml} \rightarrow 5.0 \mathrm{ml} \rightarrow 50 \mathrm{ml}$

Content of Curcumin $(\mathrm{mg} / 10 \mathrm{~g})=$

[( A / 168) X (100/W) X 1 X 100]

Where, $\mathrm{A}=$ Absorbance Reading of the sample ;

$\mathrm{W}=$ Weight of the sample in $\mathrm{g}=4$

Table 1: Formulation details: tablet, capsule, syrup with "Curcuma longa" turmeric (haldi) extract powder as a source of "Curcumin"

\begin{tabular}{|c|c|c|}
\hline Tablet & Capsule & Syrup - 1 \\
\hline $\begin{array}{l}\text { Turmeric extract powder (Haldi extract) } \\
\text { standardized for } 20 \% \text { w/w curcumin }\end{array}$ & $\begin{array}{l}\text { Turmeric extract powder (Haldi extract) } \\
\text { standardized for } 20 \% \mathrm{w} / \mathrm{w} \text { curcumin }\end{array}$ & $\begin{array}{l}\text { Turmeric extract powder (Haldi extract) } \\
\text { standardized for } 20 \% \mathrm{w} / \mathrm{w} \text { curcumin }\end{array}$ \\
\hline Each tablet of $1100 \mathrm{mg}$ & Filled weight of each capsule $480 \mathrm{mg}$ & Each $10 \mathrm{ml}$ syrup \\
\hline $\begin{array}{c}\text { Composition : } \\
\text { Each uncoated tablet contains : } \\
\text { Turmeric extract powder } \\
\text { (Curcuma longa }) \ldots 200 \mathrm{mg} \\
\text { Kali mirch extract ... } 10 \mathrm{mg} \\
\text { Excipients ... q.s. }\end{array}$ & 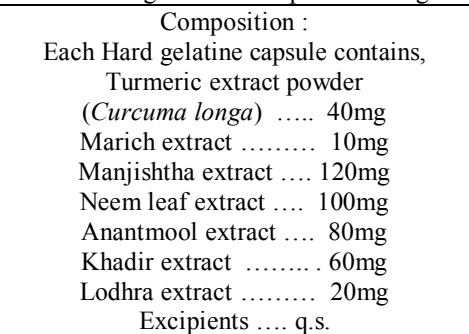 & $\begin{array}{c}\text { Composition : } \\
\text { Each } 10 \text { ml syrup contains: } \\
\text { Turmeric extract powder } \\
(\text { Curcuma longa }) \ldots 125 \mathrm{mg} \\
\text { Pippli extract........ 10mg } \\
\text { Tulsi extract ........125mg } \\
\text { Mulethi extract .....125mg } \\
\text { Excipients ... q.s. }\end{array}$ \\
\hline
\end{tabular}

Table 2: Formulation details: syrup and cream with Turmeric (haldi) oleoresin as a source of "Curcumin"

\begin{tabular}{|c|c|}
\hline Syrup 2 & Cream \\
\hline Turmeric (Haldi) Oleoresin standardized for $20 \% \mathrm{w} / \mathrm{w}$ curcumin & Turmeric (Haldi) Oleoresin standardized for $20 \% \mathrm{w} / \mathrm{w}$ curcumin \\
\hline 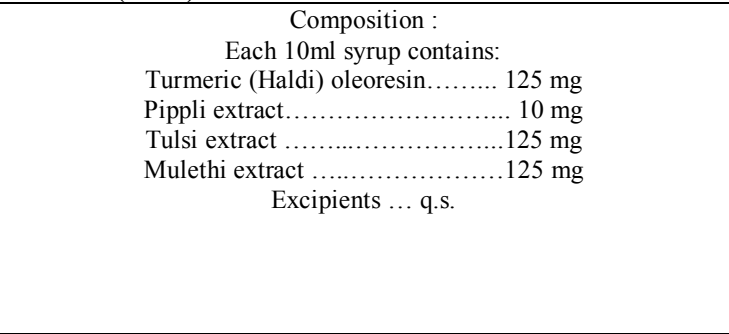 & 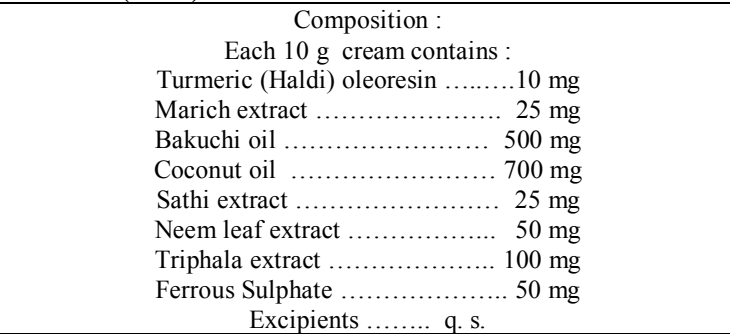 \\
\hline
\end{tabular}


Table 3: Content of "Curcumin" in different dosage forms

\begin{tabular}{|c|c|c|c|c|}
\hline \multirow{2}{*}{$\begin{array}{l}\text { Extracts / Dosage } \\
\text { form }\end{array}$} & \multicolumn{2}{|c|}{ Initial } & \multicolumn{2}{|c|}{ After a period of 1 year } \\
\hline & Curcumin Content * & Curcumin Content ** & Curcumin Content * & Curcumin Content ** \\
\hline \multicolumn{5}{|c|}{ Extracts } \\
\hline $\begin{array}{c}\text { Turmeric (Haldi) } \\
\text { (Curcuma longa) extract } \\
\text { powder } \\
\end{array}$ & $\begin{array}{l}\text { Standardised for } 20.00 \% \mathrm{w} / \mathrm{w} \\
\text { curcumin (NLT20\%w/w) }\end{array}$ & $22.10 \% \mathrm{w} / \mathrm{w}$ & $\begin{array}{l}\text { Standardised for } 20.00 \% \mathrm{w} / \mathrm{w} \\
\text { curcumin (NLT20\%w/w) }\end{array}$ & $21.00 \% \mathrm{w} / \mathrm{w}$ \\
\hline $\begin{array}{c}\text { Turmeric (Haldi) } \\
\text { oleoresin }\end{array}$ & $\begin{array}{l}\text { Standardised for } 20.00 \% \mathrm{w} / \mathrm{w} \\
\text { curcumin (NLT20\%w/w) }\end{array}$ & $21.09 \% \mathrm{w} / \mathrm{w}$ & $\begin{array}{l}\text { Standardised for } 20.00 \% \mathrm{w} / \mathrm{w} \\
\text { curcumin (NLT20\%w/w) }\end{array}$ & $14.97 \% \mathrm{w} / \mathrm{w}$ \\
\hline \multicolumn{5}{|c|}{ Dosage Forms } \\
\hline Tablet & $\begin{array}{c}\text { Not less than } \\
\mathrm{mg} / \text { tablet }\end{array}$ & $44.40 \mathrm{mg} /$ tablet & Not less than $40.00 \mathrm{mg} /$ tablet & $43.00 \mathrm{mg} /$ tablet \\
\hline Capsule & $\begin{array}{c}\begin{array}{c}\text { Not less than } \\
\text { mg/capsule }\end{array} \\
\end{array}$ & $9.09 \mathrm{mg} /$ capsule & $\begin{array}{c}\text { Not less than } 8.00 \\
\text { mg/capsule }\end{array}$ & $9.00 \mathrm{mg} /$ capsule \\
\hline Syrup - 1 & $\begin{array}{c}\text { Not less than } 250.00 \\
\mathrm{mg} / 100 \mathrm{ml}\end{array}$ & $12.26 \mathrm{mg} / 100 \mathrm{ml}$ & $\begin{array}{c}\text { Not less than } 250.00 \\
\mathrm{mg} / 100 \mathrm{ml}\end{array}$ & $7.73 \mathrm{mg} / 100 \mathrm{ml}$ \\
\hline Syrup - 2 & $\begin{array}{c}\text { Not less than } 250.00 \\
\mathrm{mg} / 100 \mathrm{ml}\end{array}$ & $240.00 \mathrm{mg} / 100 \mathrm{ml}$ & $\begin{array}{c}\text { Not less than } 250.00 \\
\mathrm{mg} / 100 \mathrm{ml}\end{array}$ & $161.90 \mathrm{mg} / 100 \mathrm{ml}$ \\
\hline Cream & Not less than $2.00 \mathrm{mg} / 10 \mathrm{~g}$ & $2.03 \mathrm{mg} / 10 \mathrm{~g}$ & Not less than $2.00 \mathrm{mg} / 10 \mathrm{~g}$ & $1.57 \mathrm{mg} / 10 \mathrm{~g}$ \\
\hline
\end{tabular}

\section{RESULTS}

Table 1 and 2 summarize the actual active ingredients in the individual sample under study.

Table 3 focuses on the "Curcumin content" in different dosage forms including Active Pharmaceutical Ingredient (API) namely. Turmeric (Haldi) extract powder and turmeric (Haldi) oleoresin.

Initial analysis data and the data of analysis of the same sample after 1 year are recorded in the table 3 . Content of curcumin is found to be around $20.00 \% \mathrm{w} / \mathrm{w}$ in turmeric extract powder, which remains stable even after 1 year. However, turmeric oleoresin gives good results at the initial level, but after 1 year it decreases from $21 \% \mathrm{w} / \mathrm{w}$ to around $14.97 \% \mathrm{w} / \mathrm{w}$. It comes out to be $75 \%$ of the labelled claim value.

Curcuma longa (Turmeric) (Haldi) extract powder is used as a source of curcumin in tablet formulation, as the blend of the tablet is in powder form. Results of curcumin content are observed to be satisfactory and stable even after 1 year at room temperature.

Similarly for capsule formulation, extract powder of turmeric is chosen as a source of curcumin, as the blend of the capsule is in powder form. Results are meeting with the specification at initial level as well as after 1 year study.

In case of syrup formulation, since syrup is in liquid form, powder form of extract creates problem with respect to solubility. During manufacturing process, at the filtration stage most of the turmeric extract powder remains unfiltered, as a result, syrup 1 mentioned in table 3 gives $12.26 \mathrm{mg}$ curcumin / 100ml syrup instead of $250 \mathrm{mg} / 100 \mathrm{ml}$ calculated value with respect to the manufacturing formula. Also because of non-uniform distribution of insoluble particles of turmeric extract powder in the sample, the result comes down up to $7.73 \mathrm{mg} / 100 \mathrm{ml}$.after a period of 1 year.

To avoid the major problem of solubility in syrup formulation, turmeric extract powder is replaced by turmeric oleoresin of same strength and this syrup 2 sample is subjected to analysis for content of curcumin. Initially the content is found to be $240 \mathrm{mg} / 100 \mathrm{ml}$, which is equivalent to $96 \%$ of the theoretically expected value. However, after a period of 1 year the results are found to be decreased to $161.90 \mathrm{mg} / 100 \mathrm{ml}$, which is equivalent to $64.76 \%$ of the theoretically expected value. This is because the Active Pharmaceutical Ingredient (API), turmeric oleoresin, used here, itself is not stable with respect to its curcumin content.
Cream formulation is made only with oleoresin, as the semisolid base of the cream does not allow the uniform distribution and homogeneity with respect to the solubility of extract powder. Turmeric oleoresin itself is in thick viscous liquid form and can be properly mixed with the cream sample. Hence the cream sample with turmeric oleoresin is analyzed for curcumin content. Results are found to be satisfactory at the initial level. Since the oleoresin is not stable for a long period, curcumin content in cream sample after a period of 1 year, is found to be $1.57 \mathrm{mg} / 10 \mathrm{~g}$ equivalent to $78.50 \%$ of the theoretical value.

\section{DISCUSSION}

Curcuma longa that is Turmeric (Haldi) extract powder can be used as a source of curcumin in certain dosage forms like tablets and capsules, where respective blends are in powdered form. However, quantitative estimation of curcumin is not possible in case of syrup formulation, due to solubility criteria of turmeric powder and its uneven distribution in the syrup. The alternative option of using turmeric oleoresin of the same strength and in the same quantity does not meet with the specification after few months, due to short shelf life of oleoresin. In cream also it shows slight deterioration after a few months. Hence turmeric oleoresin can be used as Active Pharmaceutical Ingredient (API) only for short term purpose, provided that, the oleoresin as well as its corresponding formulations, are stored at controlled conditions.

\section{ACKNOWLEDGEMENT}

The authors are thankful to the authorities of Piramal Enterprises Ltd., Goregaon R\&D Centre for providing laboratory facilities and also extend their thanks to Dr. Chauhan for his valuable support and encouragement.

\section{REFERENCES}

1. Thvar KS. Characterization of the Purity of Curcumin Extraction: Comparative study of UV Spectrophotometry and HPLC from a Field Application Perspective. The National High School Journal of Science. [Sr. No. 3]. 2013 Feb [cited 2012 Aug 15]:

2. Pal SK, Shukla Y. Herbal Medicine: Current Status and the Future. Asian Pacific Journal of Cancer Prevention 2003; 4(4):281-288.

3. Soni H, Patel SS, Mishra K, Nayak G, Singhai AK. Qualitative And Quantitative Profile Of Curcumin From Ethanolic Extract Of Curcuma Longa. International Research Journal of Pharmacy 2011; 2(4):180-184.

4. Nadkarni KM. Indian Materia Medica. CURCUMA LONGA, Linn. Vol.1. Mumbai (India): Bombay Popular Prakashan; Reprint 1986. p. 414-418.

5. Kirtikar KR, Basu BD. Indian Medicinal Plants. SCITAMINEAE. $2^{\text {nd }}$ Ed. Vol.4 (Reprint1984). Dehradun (India): Bishen Singh and Mahendra Pal Singh; 1984.p. 2423,2424. 
6. Rajpal V. Standardization of Botanicals: Testing and extraction methods of medicinal herbs. Vol.2. New Delhi (India): Eastern Publishers; 2005. p. 122,123 .

7. Zaibunnisa AH, Norashikin S, Mamot S, Osman H. Stability of Curcumin in Turmeric Oleoresin $-\beta-$ Cyclodextrin Inclusion Complex During Storage. The Malaysian Journal of Sciences 2009; 13(2): 165 169.

8. Rinwa P, Kumar A. Piperine Potentiates the protective effects of curcumin against chronic unpredictable stress-induced cognitive impairment and oxidative damage in mice. Brain Res. 2012; 1448: 3850. http://dx.doi.org/10.1016/j.brainres.2012.10.002 PMid:23099054
9. Rajpal V. Standardization of Botanicals: Testing and extraction methods of medicinal herbs. Vol.2. New Delhi (India): Eastern Publishers; 2005. p. 126,127 .

10. Indian Pharmacopoeia, Govt. of India. Ministry of Health and Family Welfare. Vol.2.Delhi (India): Published by the Controller of publications; 1996. p. A-76. Appendix 5.5.

\section{Cite this article as:}

Rane Rajashree, Gangolli Divya, Patil Sushma, Ingawale Kanchan, Kundalwal Sachin. Analytical study of Curcumin content in different dosage forms containing turmeric extract powder and turmeric oleoresin. Int. Res. J. Pharm. 2013; 4(3):182-185 